\title{
Sneddon's syndrome: case report and review of its relationship with antiphospholipid syndrome
}

\author{
Síndrome de Sneddon: relato de caso e revisão sobre a relação \\ com a síndrome do anticorpo antifosfolipídio
}

\author{
Livia Almeida Dutra ${ }^{1}$, Pedro Braga-Neto ${ }^{1}$, José Luiz Pedroso ${ }^{1}$, Orlando Graziani Povoas Barsottini²
}

\begin{abstract}
The Sneddon's syndrome is a rare disorder characterized by the occurrence of cerebrovascular disease associated with livedo reticularis. The antiphospholipid syndrome is the most frequent type of acquired thrombophilia, defined by the occurrence of thrombosis or pregnancy morbidity in the presence of persistently positive antiphospholipid antibodies. Approximately $80 \%$ of Sneddon's syndrome patients have an antiphospholipid antibody marker. These antibodies may play a pathogenetic role in some cases of Sneddon's syndrome, and many authors consider these two syndromes as the same entity. Although clinical features of antiphospholipid syndrome and Sneddon's syndrome may overlap, there is a distinction between clinical and laboratory evidence suggesting that these two entities are different diseases. A recent finding of coagulopathies, including elevated levels of coagulation factor VII, decreased levels of protein $S$, and activated protein C in Sneddon's syndrome patients suggested a possible biological link between the vasculopathy and a primary coagulopathy. Moreover, the clinical course seems to be progressive in Sneddon's syndrome patients and includes increase of disability and cognitive deterioration, more arterial involvement, and the antiphospholipid syndrome shows a more benign course. Both syndromes share clinical and laboratory features, and whether Sneddon's syndrome represents a spectrum of antiphospholipid syndrome remains unclear. Sneddon's syndrome patients have a worse prognosis and may represent a subgroup of patients who demands more rigorous follow-up. It is important to recognize the Sneddon's syndrome, particularly because stroke episodes may be prevented through appropriate treatment.
\end{abstract}

Keywords: Sneddon syndrome/immunology; Antiphospholipid syndrome/ immunology; Antibodies, anticardiolipin; Antibodies, antiphospholipid; Livedo reticularis; Stroke; Case reports

\section{RESUMO}

A síndrome de Sneddon é um distúrbio raro caracterizado pela ocorrência de doença cerebrovascular associada a livedo reticular. A síndrome do anticorpo antifosfolipídio é o tipo mais frequente de trombofilia, definida pela ocorrência de trombose ou morbidade gestacional na presença de anticorpos antifosfolípides persistentemente positivos. Aproximadamente $80 \%$ dos pacientes com síndrome de Sneddon apresentam um marcador de anticorpo antifosfolipídio. Esses anticorpos podem exercer um papel fisiopatológico em alguns casos de síndrome de Sneddon, e muitos autores consideram essa síndrome e a síndrome do anticorpo antifosfolipídio a mesma entidade. Apesar de os quadros clínicos das suas síndromes poderem se sobrepor, há evidência clínica e laboratorial distintiva, sugerindo que as duas entidades são doenças diferentes. Um achado recente de coagulopatia, incluindo níveis elevados do fator VII de coagulação, diminuição dos níveis da proteína $S$, e proteína $C$ ativada em pacientes com síndrome de Sneddon, sugeriu uma possível ligação biológica entre a vasculopatia e coagulopatia primária. Além disso, o curso clínico pareceu ser progressivo em pacientes com síndrome de Sneddon, visto que há aumento de incapacidade e deterioração cognitiva, além de maior envolvimento arterial, enquanto a síndrome do anticorpo antifosfolipídio apresenta um curso mais benigno. Ambas as síndromes compartilham características clínicas e laboratoriais; até qual ponto a síndrome de Sneddon representa um espectro da síndrome do anticorpo antifosfolipídio permanece desconhecido. Os pacientes com a primeira síndrome apresentam pior prognóstico e podem representar um subgrupo de pacientes que requer um seguimento mais rigoroso. É importante reconhecer a síndrome de Sneddon já que os episódios de acidente vascular cerebral podem ser prevenidos com a terapia apropriada.

\footnotetext{
Departament of Neurology and Neurosurgery, Universidade Federal de São Paulo - UNIFESP São Paulo (SP), Brazil.

${ }^{3}$ Departament of Neurology and Neurosurgery, Universidade Federal de São Paulo - UNIFESP, São Paulo (SP), Brazil; Instituto do Cérebro - InCe - Hospital Israelita Albert Einstein - HIAE, São Paulo (SP), Brazil. Corresponding author: Orlando Graziani Povoas Barsottini - Avenida Brigadeiro Luiz Antonio, 4.454 - Jardim Paulista - Zip code: $01402-002$ - São Paulo (SP), Brazil - Phone: (5511) 3887-0066 E-mail: orlandobarsottini@gmail.com
}

Received on: Sep 12, 2012 - Accepted on: Mar 7, 2012 
Descritores: Síndrome de Sneddon/imunologia; Síndrome antifosfolipídica/ imunologia; Anticorpos anticardiolipina; Anticorpos antifosfolipídeos; Livedo reticular; Acidente vascular cerebral; Relatos de casos

\section{INTRODUCTION}

Sneddon's syndrome (SS) is a rare disorder characterized by the occurrence of cerebrovascular disease like stroke or transitory ischemic attack associated with livedo reticularis ${ }^{(1)}$. Patients may have positive antiphospholipids (aPLs) antibodies and other manifestations of primary antiphospholipid syndrome (APS). We report a case of SS, and discuss its relation with APS.

\section{CASE REPORT}

A 41-year-old woman was referred to neurologic evaluation due to recurrent episodes of paresthesia in upper limbs for the last 20 years, lengthening for 20 minutes each episode. Twenty months before she presented an abrupt dysarthria and right hemiparesis that did not recover. At that time she was admitted for investigation. The patient developed arterial obstruction on her left foot two years before, which made her fourth toe turns blue and numb. She smoked for twenty years, had two first-trimester miscarriages and was receiving enalapril $10 \mathrm{mg}$ per day for hypertension. The patient denied any episodes of thrombosis, photosensibility, arthralgias, malar rash or oral ulcers.

General examination showed livedo reticularis involving abdominal region and upper limbs (Figure 1) and normal pulmonary and cardiac auscultation. A cold blue fourth pododactile was evident. Neurological examination revealed mild proportionate right hemiparesis with hyperreflexia and preserved sensory functions. Brain magnetic resonance imaging disclosed

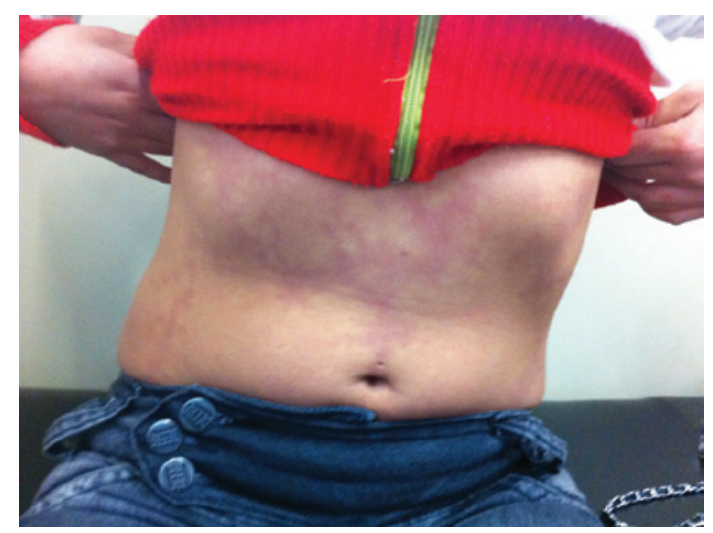

Figure 1. Livedo reticularis involving the abdominal region multiple white-matter abnormalities at frontal corticosubcortical region suggesting involvement of smallvessels (Figure 2). Spinal fluid analysis showed elevated protein $(64 \mathrm{mg} / \mathrm{dL})$ and transthoracic echocardiography, mild left atrial enlargement, thickening of the mitral valve with discrete reflux. The anticardiolipin antibodies $(\mathrm{aCL})$ and the lupic anticoagulant were negative.

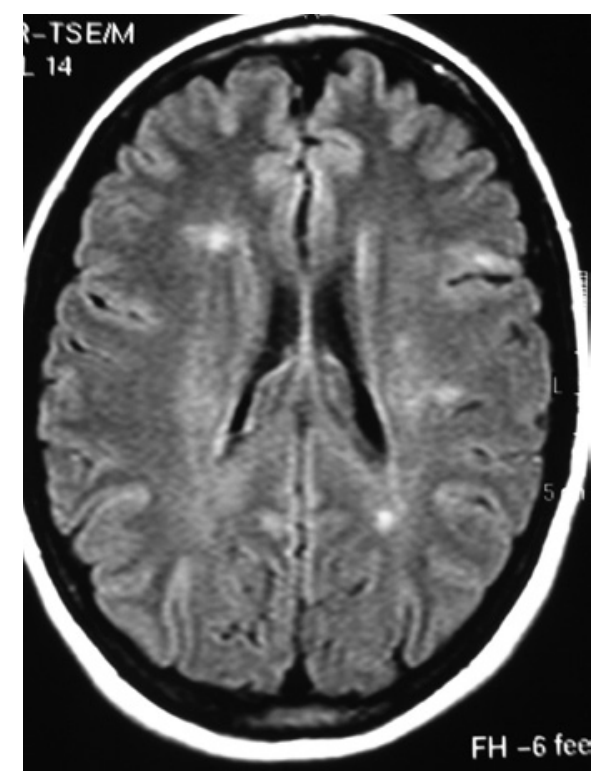

Figure 2. Magnetic Resonance (FLAIR) disclosed multiple white-matter abnormalities at frontal cortico-subcortical region

The patient was diagnosed as SS, and after three months of follow-up showed elevated IgM aCL titers that remained positive for 6 months. She was treated with oral anticoagulation.

\section{DISCUSSION}

APS is the most frequent type of acquired thrombophilia, defined by the occurrence of thrombosis or pregnancy morbidity in the presence of persistently positive aPL antibodies $^{(2,3)}$. Three aPL antibodies may be found in APS: aCL (60 to 70\%), lupus anticoagulant (20 to 30\%) and beta2-glycoprotein (5 to 10\%). The aPLs antibodies promote activation of endothelial cells, monocytes, and platelets; and overproduction of tissue factor and thromboxane A2. Complement activation might have a central pathogenetic role ${ }^{(2)}$.

The estimated annual incidence of SS is four cases per million and its precise etiology is unknown ${ }^{(1)}$. The cardinal manifestation of livedo reticularis results from thrombosis of subcutaneous arterioles and compensatory capillary dilation that causes blood to stagnate, which on the other hand causes mottled 
discoloration ${ }^{(3)}$.Histopathological analysis revealed a non-inflammatory thrombotic vasculopathy of the small and medium arteries of skin and brain ${ }^{(1,4)}$.

Approximately $41 \%$ of SS present aCL antibodies ${ }^{(4)}$. When other aPL antibodies were evaluated, such as anti-protrombin, lupus anticoagulant and antiphosphatidilethanolamine, almost $80 \%$ of SS patients had an aPL marker ${ }^{(1,5,6)}$. However, in many cases no antibodies could be found ${ }^{(7)}$. These antibodies may play a pathogenetic role in some cases of SS. In addition, some authors consider SS and APS as the same entity ${ }^{(3,4,6,8)}$.

Besides autoimmunity markers, SS and APS share clinical manifestations such as headache, hypertension, vascular dementia, involvement of cardiac valves and kidneys. Recurrent miscarriages and thrombosis could also be found in SS without aPL antibodies ${ }^{(1,4,8)}$. Other dermatological manifestations include acrocyanosis, Raynaud's phenomenon and, less frequently, circumscribed skin necrosis ${ }^{(8)}$.

It is important to determine the occurrence of cardiac manifestations in APS and SS patients. Studies suggest that valvulopathy might be a source for emboli and a possible cause of ischemic stroke. Also, there is an association between valvular heart disease and several central nervous disease manifestations in aPL positive patients, not only regarding stroke and transient ischemic $\operatorname{attack}^{(3)}$.

Although clinical features of APS and SS may overlap, there is distinctive clinical and laboratory evidence suggesting that these two entities are different diseases ${ }^{(5)}$. Several associated coagulopathies, including elevated levels of coagulation factor VII, decreased levels of protein $\mathrm{S}$, and activated protein $\mathrm{C}$ resistance have been observed, suggesting a possible biological link between the vasculopathy and a primary coagulopathy in $\mathrm{SS}^{(3,8)}$. Moreover, the clinical course seems to be progressive in SS patients and includes increase of disability and cognitive deterioration, more arterial involvement. APS shows a more benign course ${ }^{(4)}$. Despite abnormalities in thrombotic mechanisms have been described, they have not been confirmed in large series, and the presence of aPL remains the most reliable explanation for the thrombotic process, but it accounts only for a subset of SS patients ${ }^{(8)}$.
Considering secondary thromboprophylaxis, the main treatment for APS patients is anticoagulation rather than immunosuppression ${ }^{(2,3)}$. For SS patients with aPL antibodies warfarin is often used ${ }^{(1,5)}$. On the other hand, one study demonstrated that SS patients without aPL benefit from antiplatelet therapy ${ }^{(9)}$.

Our patient had livedo reticularis, pregnancy morbidity, cardiac valvular disorder and probably arterial thrombosis in inferior limbs, which are commonly associated to both disorders. In the light of information exposed, she was diagnosed as SS with positive aPL antibodies, therefore requiring anticoagulation.

In conclusion, the SS and the APS share clinical and laboratory features, and whether SS represents a spectrum of APS remains unclear. SS patients have a worse prognosis and may represent a subgroup of patients who demands more rigorous follow-up. It is important to recognize the SS, particularly because stroke episodes may be prevented through appropriate treatment.

\section{REFERENCES}

1. Aladdin $Y$, Hamadeh M, Butcher K. The Sneddon syndrome. Arch Neurol. 2008;65(6):834-5.

2. Ruiz-Irastorza G, Crowther M, Branch W, Khamashta MA. Antiphospholipid syndrome. Lancet. 2010;376(9751):1498-509.

3. Sanna G, D'Cruz D, Cuadrado MJ. Cerebral manifestations in the antiphospholipid (Hughes) syndrome. Rheum Dis Clin N Am. 2006;32(3):465-90.

4. FetoniV, GrisoliM, SalmaggiA, Carriero R, GirottiF. Clinical and neuroradiological aspects of Sneddon's syndrome and primary antiphospholipid antibody syndrome. A follow-up study. Neurol Sci. 2000;21(3):157-64.

5. Caldas CA, de Carvalho JF. Primary antiphospholipid syndrome with and without Sneddon's syndrome. Rheumatol Int. 2011;31(2):197-200.

6. Kalashnikova LA, Korczyn AD, Shavit S, Rebrova O, Reshetnyak T, Chapman J. Antibodies to prothrombin in patients with Sneddon's syndrome. Neurology. 1999;53(1):223-5.

7. Francès C, Piette JC. The mystery of Sneddon Syndrome: relationship with antiphospholipid syndrome and systemic lupus erythematosus. J Autoimmun. 2000;15(2):139-43.

8. Kalashnikova LA, Aleksandrova EN, Novikov AA, Dobrynina LA, Nasonov EL, Sergeeva EV, et al. [Anti-phosphatidylethanolamine antibodies in patients with Sneddon's syndrome]. Klin Med (Mosk). 2005;83(5):46-9. Russian.

9. Francès C, Papo T, Wechsler B, Laporte JL, Biousse V, Piette JC. Sneddon syndrome with or without antiphospholipid antibodies. A comparative study in 46 patients. Medicine (Baltimore). 1999;78(4):209-19. 